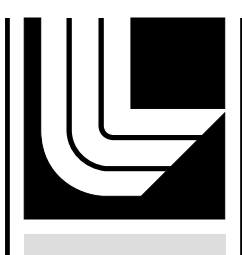

LAW RENCE LIVERMORE N A T IO N A L LABORATORY

\title{
A Top to Bottom Lithospheric Study of Africa and Arabia
}

M.E. Pasyanos

November 6, 2006

Tectonophysics 
This document was prepared as an account of work sponsored by an agency of the United States government. Neither the United States government nor Lawrence Livermore National Security, LLC, nor any of their employees makes any warranty, expressed or implied, or assumes any legal liability or responsibility for the accuracy, completeness, or usefulness of any information, apparatus, product, or process disclosed, or represents that its use would not infringe privately owned rights. Reference herein to any specific commercial product, process, or service by trade name, trademark, manufacturer, or otherwise does not necessarily constitute or imply its endorsement, recommendation, or favoring by the United States government or Lawrence Livermore National Security, LLC. The views and opinions of authors expressed herein do not necessarily state or reflect those of the United States government or Lawrence Livermore National Security, LLC, and shall not be used for advertising or product endorsement purposes. 
A Top to Bottom Lithospheric Study of Africa and Arabia

M.E. Pasyanos

October 31, 2006

Tectonophysics 
This document was prepared as an account of work sponsored by an agency of the United States Government. Neither the United States Government nor the University of California nor any of their employees, makes any warranty, express or implied, or assumes any legal liability or responsibility for the accuracy, completeness, or usefulness of any information, apparatus, product, or process disclosed, or represents that its use would not infringe privately owned rights. Reference herein to any specific commercial product, process, or service by trade name, trademark, manufacturer, or otherwise, does not necessarily constitute or imply its endorsement, recommendation, or favoring by the United States Government or the University of California. The views and opinions of authors expressed herein do not necessarily state or reflect those of the United States Government or the University of California, and shall not be used for advertising or product endorsement purposes. 


\title{
A Top to Bottom Lithospheric Study of Africa and Arabia
}

\author{
Michael E. Pasyanos \\ Lawrence Livermore National Laboratory \\ P.O. Box $808, L-205$ \\ Livermore, CA 94551-0808 \\ phone: (925) 423-6835 \\ FAX: (925) 423-4077 \\ email:pasyanos1@llnl.gov
}

Abbreviated title: Lithospheric Structure of Africa 


\begin{abstract}
We study the lithospheric structure of Africa, Arabia and adjacent oceanic regions with fundamental-mode surface waves over a wide period range. Including short period group velocities allows us to examine shallower features than previous studies of the whole continent. In the process, we have developed a crustal thickness map of Africa. Main features include crustal thickness increases under the West African, Congo, and Kalahari cratons. We find crustal thinning under Mesozoic and Cenozoic rifts, including the Benue Trough, Red Sea, and East, Central, and West African rift systems. Crustal shear wave velocities are generally faster in oceanic regions and cratons, and slower in more recent crust and in active and formerly active orogenic regions. Deeper structure, related to the thickness of cratons and modern rifting, is generally consistent with previous work. Under cratons we find thick lithosphere and fast upper mantle velocities, while under rifts we find thinned lithosphere and slower upper mantle velocities. There are no consistent effects in areas classified as hotspots, indicating that there seem to be numerous origins for these features. Finally, it appears that the African Superswell has had a significantly different impact in the north and the south, indicating specifics of the feature (temperature, time of influence, etc.) to be dissimilar between the two regions. Factoring in other information, it is likely that the southern portion has been active in the past, but that shallow activity is currently limited to the northern portion of the superswell.
\end{abstract}

Keywords: crust, Moho, upper mantle, group velocity, Africa, Arabia, lithosphere, hotspots, African Superswell 


\section{INTRODUCTION}

In general, Africa has been a poorly studied region in geophysics and the overall structure of the African continent remains one of the poorest resolved in the world. Owing both to the sparse distribution of seismic stations and to the aseismic nature of the region, extensive seismic studies of the area have been confined to a limited number of regions, which are increasingly well-resolved. For example, as of late the East African rift has been extensively studied through a number of PASSCAL deployments in Ethiopia, Kenya, and Tanzania. The Kalahari Craton in southern Africa has been similarly well studied. Outside of these limited regions and some oilrich regions like Nigeria, there have been very few widely available refraction or high-resolution seismic experiments. This is starting to change; the AfricaArray initiative is an ambitious effort to instrument the whole continent (http://africaarray.psu.edu).

More commonly, our knowledge of Africa comes from global studies. This is limiting in two respects. First, the resolution of global studies is often too low to see many of the details necessary for the complete understanding of a region. Secondly, as already mentioned, both the poor station coverage and the large aseismic regions of Africa make this area one of the poorly resolved regions in these studies. One recent study which has made a significant impact on our understanding of Africa is the work of Ritsema and van Heijst (2000), subsequently referred to as R\&VH. That study used inverse modeling of fundamental mode Rayleigh wave phase velocities (from 40 - $200 \mathrm{sec}$ ) for several thousand paths to construct a seismic model of the upper $400 \mathrm{~km}$ of the mantle beneath Africa and surrounding regions. Mantle structures related to both cratons and rift structures were observed. Because of the long-period nature of the data, however, only mantle structures were resolved, and crustal structure was simply removed using a global crustal model.

While the deeper structure is starting to be resolved, fundamental questions about shallower lithospheric structure remain. For example, while there are crustal thickness maps of Europe (Meissner et al., 1987), Asia (Kunin et al. 1987), and North America (Das and Nolet, 1998), no corresponding maps exist for the whole of the African continent. As a result, many 
questions about the lithospheric structure of Africa, even as fundamental as crustal thickness, remain unresolved. For instance, has there been any significant crustal thickening under older orogenic zones, such as the Mozambique Belt and the Atlas Mountains? Or crustal thinning under the Benue Trough? What is the crustal thickness in the North African interior? Within North Africa, is there any significant contrast between the old Precambrian crust of the Saharan Shield and the ancient Archean crust of the West African and Congo Cratons? How does the lithospheric structure near hotspots differ from nearby regions? Has there been crustal thinning in Kenya? How has the African Superswell affected overlying African crust? Given these constraints, surface waves represent one of the best means to understand the area since they can travel though regions of interest without the benefit of either seismic sources or seismic receivers within the region which, while becoming more common, are still relatively sparsely distributed.

This paper tries to ascertain the seismic structure of Africa, nearby Arabian Peninsula, and adjacent regions though the inversion of high-resolution group velocities over a wide period range. Because the dataset includes short period $(<40 \mathrm{sec})$ surface waves, it has the power to resolve features in both the crust and upper mantle. We develop an upper mantle model and compare our results to the findings of $\mathrm{R} \& \mathrm{VH}$ to see if there are any significant differences. We also focus on shallower features, develop a better understanding of the crustal structure of Africa, and in the process, create a crustal thickness map of the region. We can then start to address some of the questions about African structure by providing a model that can be tested by additional geophysical datasets in the region.

\section{BACKGROUND}

The tectonics of Africa (Figure 1) are unusual in the sense that, in general, the structure of the continent is very old and that tectonic activity more recent than the Paleozoic occurs only in limited regions. In fact, of all the continents, Africa has the highest percentage of Precambrian crust (Goodwin, 1996). Starting from the north, the tectonic structure is dominated by convergence with Eurasia. In the west, this expresses itself in the Atlas Mts. orogeny. In the Western Mediterranean, we see the subduction of the African plate along the Calabrian, Hellenic, 
and Cyprean arcs. To the northeast, the Zagros orogeny is the result of the Arabian plate converging with Eurasia. North Africa is where the West African Craton and the East Saharan Shield formed in the Pan-African orogeny during the late Precambrian. North Africa is also dotted with several hotspots including the Hoggar in southern Algeria, Tibesti in northern Chad, and Darfour in western Sudan. Offshore, we find hotspots associated with the Canary and Cape Verde Islands.

East Africa is where we find most current tectonic activity. The Red Sea Rift has split the Nubian and Arabian Shields; the Gulf of Aden separates the Arabian and Somali Plates; and the East African Rift is starting to separate the Somali Plate from the rest of Africa. These three rift zones form a triple junction in the Afar. This area also sits at the northern edge of the African Superswell, a buoyant region under eastern and southern Africa responsible for high residual topography (Nyblade and Robinson, 1994). Rifting in the south continues along the Eastern and Western Branches of the East African Rift System. Earlier rifting during the opening of the Atlantic in the Jurassic produced the failed West and Central African Rift Systems. The Benue Trough and the Central African Rift System occur to the north of another feature of the Pan-African orogeny, the Central African Belt, which resulted from the collision of the North African Craton with the Congo Craton. The Pan-African orogeny also formed the Mozambique Belt in East Africa.

Moving further to the south, the Katanga Belt runs east-west between the Congo and Kalahari Cratons. The Kalahari Craton occupies most of southern Africa and is comprised of several major provinces. Trending from north to south, we find the Zimbabwe Craton, the Limpopo Belt, the Kaapvaal Craton, and the Namaqua-Natal Mobile Belt. Finally, at the southern tip of the continent, the Cape Fold Belt was formed as part of the Gondwanide orogen with proto-South America and proto-Antarctica. To the west, we find the St. Helena and Ascension Island hotspots, while to the east, we find Madagascar, and the Comores and Reunion Islands hotspots. Starting during the Jurassic, Madagascar along with India, Antarctica and Australia, split off from the Somali Coast and traveled south before first splitting from Antarctica and Australia ( 130 Ma), and then India ( 90 Ma) during the Cretaceous. 
Throughout Africa, we find a large number of sedimentary basins. Using the system of Clifford (1986), the basins can be classified as interior basins (large basins within stable continental shield) like the Taoudenni and Etosha Basins, marginal sag basins (basins located at the continental edge) such as the Somali and Mozambique Basins, rift basins like the Benue Trough and East African and Sirt Basins, and composite and complex basins, such as the Congo and Illizi Basins (Schlüter, 2006).

Another significant influence for the continent is the African Superswell (Nyblade and Robinson, 1994). This large feature has elevated significant portions of the African continent along a swath running from south of Africa to the middle of the Arabian Peninsula, and has been observed seismically down to the core-mantle boundary (Ritsema et al., 1999). Besides the high dynamic topography, visible features of the superswell include major volcanic episodes, heat flow measurements in southern Africa, and rifting and volcanism in eastern Africa and the Afar region. Global tomography models (e.g. van der Hilst et al., 1997) have persistently found low velocities beneath this region.

\section{DATA AND MEASUREMENTS}

Our main source for station coverage of the region comes from stations in the Global Seismic Network (GSN). In Africa and Arabia, these stations include AAE, FURI, KOWA, KMBO, LBTB, LSZ, MBAR, MBO, MSKU, RAYN, SUR, and TSUM. Offshore, these include stations ASCN, DGAR, MSEY, SACV, and SHEL. Other contributing FDSN stations include those from the GEOSCOPE network (TAM, ATD/AGD, RER), the MEDNET network (GFA, MDT, MEB), and other U.S. networks (BGCA, DBIC, BOSA). Coverage of several regions was significantly improved with PASSCAL deployments in Tanzania (Nyblade et al., 1996), Saudi Arabia (Vernon et al., 1996), Ethiopia and Kenya (Nyblade and Langston, 2000), South Africa (Nguuri et al., 2001), and is continuing with a deployment in Cameroon. We have used data from the one open station (CM18) in this deployment. Data from several stations (ABSA, CDLV, GHAR, MARJ) in the MIDSEA deployment (van der Lee et al., 2001) improved 
coverage in North Africa. In some instances, particularly in the Middle East, we made use of data from local seismic networks including those in Jordan (HIT, RUW), Kuwait (KBD), Iraq (BHD, MSL), Libya (GHAR, MARJ), and the United Arab Emirates (MEZE, HALE).

Using these stations, we have made surface wave dispersion measurements for tens of thousands of paths across Africa. Surface wave path coverage is shown in Figure 2. Seismicity along the mid-Atlantic rift, Indian ridge, East African Rift, Red Sea, Gulf of Aden, and along the Tethys collision zone provide the bulk of events for dispersion analysis. Overall, we have excellent path coverage of the region. Clearly, however, we have better coverage (greater path density and more crossing paths) in North Africa and Arabia than for southern Africa and the south Atlantic. Path coverage is generally poorer for Love waves than Rayleigh waves, and the number of paths drops off significantly at the shortest periods $(\leq 10 \mathrm{sec})$.

Surface wave group velocities for the region are determined using seismic tomography. We use the latest updates of the group velocity maps of Pasyanos (2005). The inversion uses a $1^{\circ}$ by $1^{\circ}$ equal area grid, and a conjugate gradient method is used to solve for lateral variations in group velocity. A variable smoothness technique is used to improve the resolution of the model. The maps provide group velocities of Love and Rayleigh waves across the region for periods from 7 to 100 seconds.

Surface wave tomography maps for two periods are shown in Figure 3. The first is for $20 \mathrm{sec}$ Rayleigh waves (Figure 3a), which are generally sensitive to shallow structure. Fast group velocities at this period correspond to thin, oceanic crust, not only in the Atlantic and Indian Oceans, but also in the Western Mediterranean Sea, Red Sea, and Gulf of Aden. Slow group velocities correspond to large sedimentary basins as illustrated with the Eastern Mediterranean, Black Sea, North and South Caspian Basins, and Persian Gulf. Within Africa itself, we find slow velocities associated with the Illizi basin in Algeria and Tunis, the Taoudenni Basin in Mauritania and Mali, the basins in Somalia, and the Congo Basin. Offshore basins do not appear as slow features on this map because of the counter-effect of thin underlying crust. 
At 60 seconds, the Rayleigh waves are much more sensitive to upper mantle structure. In Figure 3b, slow velocities are associated with either slow upper mantle velocities or thick crust (i.e. Zagros Mts.). Plate boundaries, in particular, stand out and include both divergent boundaries, such as the mid-Atlantic ridge, Indian ridge, Red Sea rift, and Benue Trough, and convergent boundaries, such as the Tethys Belt. Fast velocities stand out under continental cratons and old oceanic crust. In East Africa, we can see the two branches of the East African Rift System encircling the fast Tanzania Craton.

We assess the reliability of the surface wave group velocities with uncertainty maps. Uncertainties are calculated using a bootstrapping approach described in Pasyanos et al. (2001). Using this method uncertainties are calculated by way of multiple inversions on several realizations of the data and a randomized starting model. The uncertainty map for $20 \mathrm{sec}$ Rayleigh waves is show in Figure 4. As expected from path coverage, southern Europe and the Middle East are very reliably determined, as is the strip of seismicity running along East Africa. Uncertainties are slightly higher, but still low, in the Mediterranean Sea, within most of continental Africa, and along the mid-Atlantic and mid-Indian rifts. Results are generally less reliable in the ocean away from the rifts and in Madagascar (where measurements from a planned station are not yet included), and the uncertainties are high in region south and southeast of Africa.

The resolution of the surface waves is plainly sensitive to path coverage. Resolution will also be limited by the wavelengths of the surface waves. At short periods ( $<30$ seconds), the wavelengths are less than $1^{\circ}$, so we should have high resolution for shallow structure (e.g. sediments, upper crust), at least where we have fairly good path coverage. For intermediate periods $\left(30-60\right.$ seconds), the wavelengths range from $1^{\circ}$ to $2^{\circ}$ and we will have resolution on this order for deeper structure like crustal thickness and upper mantle velocity. Wavelengths are longer than $2^{\circ}$ at long periods ( $>60$ seconds), indicating that these are the best resolutions we can hope to achieve for deeper mantle structure.

\section{METHODOLOGY}


We use the group velocities determined using seismic tomography to estimate crustal structure. At each point in our model, we collect the group velocities (and associated uncertainties) of both Love and Rayleigh waves for periods from 7 to 100 seconds. We then use a modification of the Pasyanos and Walter (2002) grid search to invert for the best 1-D isotropic velocity model which fits the scaled dispersion data (dispersion scaled by the uncertainty) at that point. Like the previous grid search methodology, we solve for crustal thickness, average crustal velocity, and the velocity of the uppermost mantle. The sediment profile is fixed based on the sediment model of Laske and Masters (1997). The modification to the search that we make here is the introduction of a lithospheric lid layer overlying an asthenospheric layer which has a high Poisson's ratio $(\sigma=0.30)$ and lower shear-wave velocities. Having this layer allows us to fit the long period surface waves which we are unable to fit with a single layer upper mantle. In the grid search, we solve for the thickness of this layer. Starting values for lithospheric thickness are derived from the group velocity - lithospheric thickness relationship (equation 5) developed in Pasyanos (2005).

Figure 5 shows examples of the grid search for seismic structure for two locations in North Africa. In each figure, the panel to the left shows the fit of dispersion predicted by the model to the group velocities derived from seismic tomography, while the panel to the right shows the resulting model. Uncertainties in the group velocities are highly dependent on period and wavetype. The uncertainties are higher for Love waves and at the longest and shortest periods, primarily due to poorer path coverage. As illustrated in Figure 5a for a profile in West Africa, even simple lithospheric models (shown in the right panel) are able to fit the surface waves, although many of the details of the profile such as the sharpness of the Moho discontinuity cannot be resolved by the surface waves. In this case, we find the surface waves fit by a velocity profile of $35 \mathrm{~km}$ thick crust with thin sediments $(1.5 \mathrm{~km})$, very fast upper mantle velocities $(4.67 \mathrm{~km} / \mathrm{s})$, and a thick lid (which extends in this case down to $280 \mathrm{~km}$ ).

The velocity model that is found for a region in East Africa looks very different (Figure 5b). The dispersion curves that we see for this region are slower than those for West Africa, 
particularly at the longest periods where we see a reduction in the group velocities of the Rayleigh waves at periods longer than about 50 seconds. Once again, though, we are able to fit the dispersion data with a simple model, although there appears to be some misfit between the input sediment profile and the short period Love waves. Here, we see a thin ( $25 \mathrm{~km}$ thick) crust with $4 \mathrm{~km}$ sediments and slower upper mantle velocities. In addition, we find that a thinner lid thickness is necessary in order to fit the observed long period surface wave data. It also appears that some transverse anisotropy (with $\mathrm{v}_{\mathrm{SH}}>\mathrm{v}_{\mathrm{SV}}$ ) might be necessary in order to simultaneously fit both the Love and Rayleigh wave dispersion.

\section{RESULTS}

By assembling the individual 1-D inversions, we have created a 3-D model for Africa and use the results to map regional lithospheric structure. Figure 6a shows a crustal thickness map for the region. The most outstanding features are the significantly thinner crust in oceanic regions, not only the Atlantic and Indian Oceans, but also the Red Sea and Mediterranean Basins (i.e. Western Mediterranean and Ionian Basin). More interesting are the variations within oceanic regions and the African continent. In the oceans, we find several instances of increases in crustal thickness associated with islands such as Ascension, Tristan du Cunha, and Reunion, as well as increases in and around Madagascar and the Mozambique Channel. Within Africa, we find thicker crust (>35 km) in the West African, Congo, and Kalahari cratons, in contrast to the moderate thicknesses in the East Saharan Shield $(25-35 \mathrm{~km})$. In general, we find a relatively gradual increase in crustal thickness from the oceanic edges of the continent to the continental interior. This is in stark contrast to what is surmised in some of the global maps based on geophysical inference (CRUST5.1, CRUST2.0), which predict abrupt boundaries. This phenomenon is well illustrated in Libya, Morocco, and Angola. Another notable feature is the crustal thinning $(<25 \mathrm{~km})$ we see in the Benue Trough and its northern and eastern extensions.

To the northeast, we see a gradual increase along the Arabian Peninsula from the Red Sea ( $<10 \mathrm{~km}$ thickness) across the shield and platform to the Zagros Mts. and Iranian Platform (> 45 $\mathrm{km})$. We also find thick crust in the Turkish Plateau and Eastern European Platform, but thin 
crust in the extended crust of Western Europe. Along the subduction zone in the eastern Mediterranean, the slow shear wave velocities due to the presence of volatiles and partial melting in the mantle wedge were being interpreted as crustal velocities and the crustal thickness were vastly overestimated. In the case of several nodes from this region, we needed to alter the range of crustal thickness to be less than $45 \mathrm{~km}$.

Another interesting indicator of regional tectonics is the map of average crustal shear velocity (Figure 6b). Here we typically find faster crust in oceanic regions (Atlantic, Mediterranean, Red Sea, etc) at least in the well-resolved oceanic regions at the edges of the continents. In general, we see a correlation between crustal velocities and the age of the latest thermo-tectonic event, with more recently affected crust (like the extended crust in western Europe) having slower velocities than less-recently affected crust. In particular, we can see slower crust in orogenic regions (Atlas Mts., Zagros Mts., Turkish-Iranian Plateau), Mozambique, and Madagascar. It also appears that the Benue Trough has slow crustal velocities. This is consistent with a number of profiles averaged by crustal types (Fig 2 in Rudnick and Fountain, 1995; Fig. 2 in Mooney et al., 1998, Fig. 12 in Pasyanos and Walter, 2002) which find fast crustal velocities in oceanic regions and slow crustal velocities in orogenic zones (including Paleozoic orogens) and extensional region (but not active rifts). In contrast, cratons have high average crustal velocities. In oceanic regions farther away from the continents, we don't see any coherent pattern, probably due to the poorer path coverage at short periods necessary to robustly estimate this parameter.

Shear wave velocities in the upper mantle directly beneath the Moho (Figure 6c) show dramatic contrasts between the cratons (West African, Congo, Ukraine, Kalahari Craton) which are associated with fast velocities, and the rifts (Dead Sea Rift, Red Sea, Gulf of Aden, East African, mid-Atlantic) associated with slow velocities. In comparison to these very slow regions, the Benue Trough and its northern and eastern extensions are only marginally slow, indicating that this rift zone is healing, at least at shallow depths. Another interesting feature are some of the linear marks in Arabia and the south Atlantic. In both cases, these correspond to know volcanic features such as recent Arabian volcanism and the Tristan hotspot track. In 
southern Africa, we find fast mantle velocities in the Kalahari Craton, but slower velocities at the southern edge of the continent. The fast velocities are consistent with previous studies of the region (Zhao et al., 1999; James et al., 2001), with the latter also finding slower velocities in the Cape Fold Belt. There does not seem to be any systematic difference in the uppermost mantle velocities of Archean and post-Archean terranes.

For completeness, we have also included a plot (Figure 6d) of the input sediment model of Laske and Masters (1997).

When we investigate the features designated as hotspots, we don't find any consistent changes in seismic structure. In regions where the hotspots are associated with plate boundaries (such as Afar and Ascension) the effects appear to be strong. In a continental setting, the Afar hotspot results in thinned crust, but in an oceanic setting, the Ascension hotspot has thickened crust. In both instances, we see very slow upper mantle velocities and thinned lithosphere. The Mt. Cameroon hotspot seems to have a lot in common (thinned crust, slow upper mantle velocities, and thinner lithosphere) with the continental Afar hotspot. In hotspots away from plate boundaries (Hoggar, Tibesti, Darfour, Canary, Reunion, Cape Verde), the effect on lithospheric structure appears to be weaker and less consistent. Under most, we find slow Sn velocities, but this effect is much stronger under some hotspots than others. In some regions, lithospheric thickness appears to be thinner, in other regions the opposite. It is likely, therefore, that there is no consistent source of these features and that they probably have different origins.

Figure 7 shows horizontal slices through the model at 100 km, 150 km, 200 km, and 250 $\mathrm{km}$ depth. The depths were chosen to allow a direct comparison to the results of R\&VH. At all depths, there is excellent agreement between the two studies, with both having high velocity structures beneath the West African, Congo and Kalahari cratons down to about $250 \mathrm{~km}$ depth, and low velocity structures observed beneath the East African, Red Sea, Gulf of Aden, midAtlantic and northwestern Indian Ridge. Regions where we find some differences are in South Africa and the Zagros Mts. 
In South Africa, R\&VH find more or less a continuous zone of thick fast lithosphere that extends from the northern edge of the Congo Craton to the southern continental edge. This study sees the same feature, but the nature of it changes in the vicinity of Namibia, Botswana, and Zimbabwe, where the Kaapvaal Craton abuts with the Congo and Zimbabwe Cratons along the Kheiss and Limpopo Belts. The models differ as well in the Zagros Mts. of Iran where R\&VH find thick lithosphere extending down to $200 \mathrm{~km}$. This is in contrast to the relatively thin lithosphere found in the model presented here. Priestley and McKenzie (2006) find even thicker lithosphere $(\sim 300 \mathrm{~km})$ beneath the Zagros. Overall, however, these differences are quite minor and the two studies find very consistent results for the mantle.

In Figure 8, we take two cross-sections through the model. The first (Figure 8b), extending from the north Atlantic to the Indian Ocean, cuts across the West African, Congo, and Tanzanian cratons. All three cratons have both fast upper mantle velocities and thick lithosphere. The Tanzania Craton is noticeably thinned on both ends where the cross-section crosses the two branches of the East African Rift and has the shallowest root of the three. In the Benue Trough, we find thinned lithosphere, but still relatively fast upper mantle velocities. The slowest upper mantle velocities along the section are found at the southeastern portion of the cross-section and are associated with the Comores Island hotspot. The second cross-section (Figure 8c) extends from the south Atlantic to the Arabian Plate along the African Superswell. Here, we find thick lithosphere associated with the cratons in southern Africa and both thinned lithosphere and slow upper mantle velocities along the East African Rift. Even away from the rift zone, however, the mantle appears to be slower under the northern portion of the superswell than neighboring regions. At the northeast end, the lithosphere thickens again under the Arabian Platform.

\section{COMPARISONS}

We compare our crustal thickness map to the velocities from two a priori geophysical models: CRUST2.0 (Bassin et al., 2000) and 3SMAC (Nataf and Ricard, 1996). Like the CRUST5.1 model (Mooney et al., 1998), CRUST2.0 is based on regional studies when available, 
and on geophysical inference when they are not. Since these studies are not available for large portions of Africa, the CRUST2.0 crustal thickness maps for this area are, in large part, inferred. We find several major differences between the crustal thickness estimates of CRUST2.0 and this model. First, while the crustal thickness in the West African, Congo, and Kalahari Cratons is thick in both models, there is a significant difference in the East Saharan Shield. This model has crustal thicknesses ranging from $25-35 \mathrm{~km}$ for this region, while CRUST2.0 finds thicknesses between 35 and $45 \mathrm{~km}$, leading to significant differences in the southern Sahara (Niger, Chad, Sudan).

Further to the south, this study finds crustal thinning associated with the Benue Trough and continuing through southern Chad and Sudan into Kenya. While the CRUST2.0 model does not have any crustal thinning associated with these features, a study in Kenya using surface waves and receiver functions also finds thinned crust (Benoit et al., 2006). As mentioned earlier, there seems to be a contrast in the crustal thickness variations along continental margins. While CRUST2.0 has abrupt boundaries, the crustal thickness model presented here has more gradual crustal thickness variations between oceanic crust and the continental margins. This could either be due to limitations of using geophysical inference or a result of the limitations of resolution for surface waves.

Another region showing a large difference is the island of Madagascar. While CRUST2.0 has a crustal thickness of about $40 \mathrm{~km}$ for this region, our model finds crustal thicknesses of 25-35 km. Reviewing a number of studies, de Wit (2003) suggests a continental crust of 30-42 km below the center of Madagascar that rapidly thins to about $25-27 \mathrm{~km}$ along the east coast, along with a lithospheric thickness ranging from 70-130 km.

A comparison of our crustal thickness map to the 3SMAC model appears to be a better match. Like our study, the 3SMAC Moho model does not have sharp boundaries right at the continental margins. The model finds crustal thickness increases in North Africa and the Congo Craton, but doesn't have any thickening associated with the cratons in southern Africa. There is also some thinning associated with the Benue Trough, although the thinning does not extend into 
the West and Central African rift systems. Finally, the crustal thickness for Madagascar in 3SMAC $(25-35 \mathrm{~km})$ is more in line with our study than CRUST2.0.

In several areas, crustal thicknesses were determined either through gravity or receiver function studies. In West Central Africa using gravity data, Poudjom Djomani et al. [1995] found crustal thickness variations ranging from $14 \mathrm{~km}$ to $45 \mathrm{~km}$, where the thinnest crust was observed under SW Chad $(\sim 14 \mathrm{~km})$ and the Benue Trough $(\sim 18 \mathrm{~km})$, while the thickest crust was found under the Congo Craton $(\sim 45 \mathrm{~km})$. This is consistent with all of our observations. In North Africa, a comparison between our crustal thickness map to one estimated using gravity (Dial, 1998) also shows excellent agreement. Both studies show thinning in the Benue Trough (extending north and east into the continental interior) and along the northern portion of the East African Rift. Both studies find about the same crustal thicknesses under the cratons, although this study shows more variation within the West African Craton than the gravity study.

In Last et al. [1997], calculating receiver functions from the Tanzania Broadband Seismic Experiment, the study found Moho depths and average crustal shear wave velocities between 36 - $42 \mathrm{~km}$ and $3.79 \mathrm{~km} / \mathrm{s}$ in the Tanzania Craton, $36-39 \mathrm{~km}$ and $3.74 \mathrm{~km} / \mathrm{s}$ in the Mozambique Belt to the east, and $40-45 \mathrm{~km}$ and $3.74 \mathrm{~km} / \mathrm{s}$ in the Ubendian Belt to the south. In comparison, our study finds slower crustal shear wave velocities in the Mozambique Belt. A similar study across Ethiopia and Kenya by Dudga et al. [2005] found a crustal thickness of 37-42 km across Kenya, 33-44 km in the Ethiopian Highlands, and 27-38 km in the Main Ethiopian Rift. We find generally consistent results in Ethiopia, but thinner crust along the Kenya Rift.

Further to the south, Nguuri et al. [2001] estimated crustal thickness from the southern Africa seismic experiment using receiver functions. The authors find thin crust $(\sim 35-40 \mathrm{~km})$ along the undisturbed areas of the craton (Kaapvaal craton, Zimbabwe craton) and thicker crust $(\sim 45-55 \mathrm{~km})$ along the Bushveld region and the Limpopo and Namaqua-Natal mobile belt, resulting in alternating bands of thin and thick crust from Capetown northeast into Zimbabwe. This is somewhat in contrast to the general progression that we see from thick crust in the 
northeastern part of the study to thinner crust to the southwest, with pockets of thinner crust at the northwest and southeast edges.

We also compare our upper mantle velocity results to the velocities from the CRUST2.0 and 3SMAC models. Again, the fit to the CRUST2.0 model is rather poor. The model has uniform, extremely fast $(\sim 4.7 \mathrm{~km} / \mathrm{s})$ upper mantle velocities throughout the African continent, except along the East African Rift Zone. In contrast, the fit to the 3SMAC model is rather good. Like our results, this model also predicts moderately slower velocities outside of the extremely fast cratons, although the velocities are even slower in our model. Overall, it seems that the 3SMAC model is the better predictor of seismic structure in Africa than CRUST2.0.

In addition to comparing our crustal thickness maps and upper mantle velocity maps with other estimates, we can compare our lithospheric thickness estimates with other studies. In Artemieva and Mooney (2001), the authors use heat flow data to estimate temperatures in the upper mantle and use the projected temperatures to derive lithospheric thickness. While heat flow coverage in Africa is spotty, where they have been able to make estimates, the patterns are very similar. Both the seismic and heat flow data find thick lithosphere under the West Africa, Congo, and Kalahari Cratons and thin lithosphere in East Africa. Moreover, both studies find the thickest lithosphere among the cratons in West Africa. Where the studies differ is in the lithospheric thickness of the Benue Trough and the eastern portion of the Saharan Shield. In both cases, the seismic thicknesses are significantly thinner than estimates of the thermal thicknesses which approach $200 \mathrm{~km}$. In each instance, however, the regions are far from the location of any heat flow measurements used in the analysis.

Priestley et al., (2006) recently estimates a lithospheric thickness of $175 \pm 25 \mathrm{~km}$ for southern Africa. Our estimates are close to this for the full Kalahari craton, but are closer to 200 $\mathrm{km}$ for the Kaapvaal and $250 \mathrm{~km}$ for the Zimbabwe craton, making it more consistent with RV\&H, but not as deep as body wave estimates (James et al., 2001). 


\section{DISCUSSION}

We have used surface wave group velocities to invert for the lithospheric structure of Africa and Arabia, including a underivative crustal thickness map of the region. Deep features in the model as characterized by horizontal slices through the upper mantle, correspond well with

other studies of the region. Shallow features like crustal thickness, however, differ significantly from some models based on geophysical inference. In particular, we find significant increases in crustal thickness associated with the West African Craton, the Congo Craton, Tanzania Craton, and Kalahari Craton. We also find thinning associated with the East, Central and West African Rift Systems. No significant variations in crustal thickness appear to the related to hotspots located away from plate boundaries. Crustal velocities are notably slower in more recently affected crust and in orogenic zones both older and more recent.

Shallow upper mantle structure shows velocity variations consistent with tectonic structure. Slow upper mantle velocities are found in the Red Sea, Dead Sea Rift, Gulf of Aden, East African Rift, and mid-Atlantic rift. Very fast upper mantle velocities are found beneath the West African Craton, Congo Craton and cratons in southeast Africa (Zambia, Zimbabwe, Tanzanian, Kaapvaal) with slow velocities in the Cape Fold Belt. The Benue Trough appears to be a deeper mantle feature only, with thinned crust and thinned lithosphere, but not particularly anomalous velocities in the upper mantle directly beneath the Moho discontinuity. Deeper structure is also well correlated to cratonic structure and is very consistent with the results of Ritsema and van Heijst (2000).

It appears that the African Superswell, which is responsible for the uplift of eastern and southern Africa, is a shallow seismic feature only beneath the northern portion of the superswell. Seismically, we do not see this feature in the south at depths for which we have surface wave sensitivity. This is consistent with the "lava lamp" model (Ladbury, 1999) advocated by Doucouré and de Wit (2003) and supported by other seismic data (Ritsema et al., 1999; Behn et al., 2004). In this model, the superswell has been only episodically active at shallow depths, 
coinciding with progressing magmatic events in southern Africa during the Jurassic, in southwest Africa during the Cretaceous, in east Africa during the Tertiary, and in northeastern Africa today.

We look forward to finding ways of further improving the lateral and depth resolution of this model. Some gains could be made by incorporating more surface wave measurements into the model, such as those from a current broadband deployment in Cameroon and planned stations in Madagascar. It would also be useful to put additional constraints on the model with data sets other than surface waves, such as teleseismic receiver functions and body wave travel times, particularly regional travel times that are sensitive to crustal and uppermost mantle structure. More seismic data and measurements across broad regions of the continent could go a long way to improving our knowledge of African earth structure.

Acknowledgments. We thank all of the people and groups contributing data to this study, including IRIS (www.iris.edu). We particularly appreciate IRIS's new single "open station" policy for ongoing PASSCAL experiments. I am grateful for Andy Nyblade's efforts in deploying stations in Africa. Maggie Benoit and Shannon Hazler made surface wave dispersion measurements included in this study. Terri Hauk assembled most of the data used in this project. Figures were generated using the Generic Mapping Tools (GMT) software (Wessel and Smith, 1998). This work was performed under the auspices of the U.S. Department of Energy by University of California Lawrence Livermore National Laboratory under contract number W7405-ENG-48. This is LLNL contribution UCRL-JOUR-******. 


\section{REFERENCES}

Artemieva, I.M., and W.D. Mooney (2001), Thermal structure and evolution of Precambrian lithosphere, J. Geophys. Res., 106, 16387-16414.

Bassin, C., G. Laske, and G. Masters (2000), The Current Limits of Resolution for Surface Wave Tomography in North America, EOS Trans AGU, 81, F897.

Behn, M.D. C.P. Conrad, and P.G. Silver (2004), Detection of upper mantle flow associated with the African Superplume, Earth. Planet. Sci. Lett., 224, 259-274.

Benoit, M., A.A. Nyblade, and M.E. Pasyanos (2006), Crustal thinning between the Ethiopian and East African Plateaus from modeling Rayleigh wave dispersion, submitted to Geophys. Res. Lett.

Clifford, A.C. (1986), African oil - past, present and future, in M. T. Halbouty, ed., Future petroleum provinces of the world: American Association of Petroleum Geologists Memoir 40, 339-372.

Das, T., and G. Nolet (1998), Crustal thickness map of the western United States by partitioned waveform inversion, J. Geophys. Res., 103, 30021-30038.

de Wit, M.J. (2003), Madagascar: Heads it's a continent, tails it's an island, Annu. Rev. Earth Planet. Sci., 31, 213-248, doi:10.1146/annurev.earth.31.100901.141337.

Dial, P.J. (1998), An integrated geophysical study of North African and Mediterranean Lithospheric Structure, Ph.D. Thesis, University of Texas at El Paso, 226 pp.

Doucouré, C.M., and M.J. de Wit (2003), Old inherited origin for the present near-bimodal topography of Africa, J. Afr. Earth Sci, 36, 371-388. 
Dugda, M.T., A. A. Nyblade, J. Julia, C. Langston, C. Ammon, and S. Simiyu (2005), Crustal structure in Ethiopia and Kenya from receiver function analysis: Implications for rift development in eastern Africa, J. Geophys. Res.,110, B01303, doi:10.1029/2004JB003065.

Goodwin, A.M. (1996), Principles of Precambrian Geology, Academic Press, New York, 327 pp.

James, D.E., M.J. Fouch, J.C. VanDecar, S. van der Lee, and Kaapvaal Seismic Group (2001), Tectospheric structure beneath southern Africa, Geophys. Res. Lett., 28, 2485-2488.

Kunin, N. and others (1987), Map of depth to Moho, Institute of Physics of the Earth: Moscow, Russia (map).

Ladbury, R. (1999), Model suggests deep-mantle topography goes with the flow, Physics Today, $52,21-24$.

Laske, G. and G. Masters (1997), A Global Digital Map of Sediment Thickness, EOS Trans. AGU, 78, F483.

Last, R.J., A.A. Nyblade, C.A. Langston, and T.J. Owens (1997), Crustal structure of the East African Plateau from receiver functions and Rayleigh wave phase velocities, J. Geophys. Res., 102, 24469-24483.

Meissner, R., T. Wever, and E.R. Fluh (1987), The Moho in Europe - Implications for crustal development, Ann. Geophys., 5B, 357-364.

Midzi, V. (2001), 3-D surface wave group velocity distribution in Central-Southern Africa, J. Seism., 5, 559-574. 
Mooney, W.D., G. Laske, and T.G. Masters (1998), CRUST 5.1: A global crustal model at $5^{\circ} x$ $5^{\circ}$, J. Geophys. Res., 103, 727-747.

Nataf, H.-C., and Y. Ricard (1996), 3SMAC: an a priori tomographic model of the upper mantle based on geophysical modeling, Phys. Earth Planet. Inter., 95, 101-122.

Nguuri, T.K., J. Gore, D.E. James, S.J. Webb, C. Wright, T.G. Zengeni, O. Gwavava, J.A. Snoke, and Kaapvaal Seismic Group (2001), Crustal structure beneath southern Africa and its implications for the formation and evolution of the Kaapvaal and Zimbabwe cratons, Geophys. Res. Lett., 28, 2501-2504.

Nyblade, A.A. and S.W. Robinson (1994), The African superswell, Geophys. Res. Lett., 21, 765768.

Nyblade, A.A., and C.A. Langston (2002), Broadband seismic experiments probe the East African Rift, EOS Trans. AGU, 83, 405-408.

Nyblade, A.A., C. Birt, C.A. Langston, T.J. Owens, and R.J. Last (1996), Seismic experiment reveals rifting of craton in Tanzania, EOS Trans. AGU, 77, 517, 520-521.

Pasyanos, M.E. (2005), A variable-resolution surface wave dispersion study of Eurasia, North Africa and surrounding regions, J. Geophys. Res., 110, B12301, doi:10.1029/2005JB003749.

Pasyanos, M.E., W.R. Walter, and S.E. Hazler (2001), A surface wave dispersion study of the Middle East and North Africa for Monitoring the Comprehensive Nuclear-Test-Ban Treaty, Pure App. Geophys., 158, 1445-1474.

Pasyanos, M.E., and W.R. Walter (2002), Crust and upper mantle structure of North Africa, Europe, and the Middle East from inversion of surface waves, Geophys. J. Int., 149, 462-480. 
Poudjom Djomani, Y.H., J.M. Nnange, M. Diament, C.J. Ebinger, and J.D. Fairhead (1995), Effective elastic thickness and crustal thickness variations in west central Africa inferred from gravity data, J. Geophys. Res., 100, 22047-22070.

Priestley, K. and D. McKenzie (2006), The thermal structure of the lithosphere from shear wave velocities, Earth. Planet. Sci. Lett., 244, 285-301.

Priestley, K., D. McKenzie, and E. Debayle (2006), The state of the upper mantle beneath southern Africa, Tectonophys., 416, doi:10.1016/j.tecto.2005.11.024, 101-112.

Ritsema, J., and H. van Heijst (2000), New seismic model of the upper mantle beneath Africa, Geology, 28, 63-66.

Ritsema J., H.J. van Heijst, and J.H. Woodhouse (1999), Complex shear wave velocity structure imaged beneath Africa and Iceland, Science, 286, 1925-1928.

Rudnick, R.L. and D.M. Fountain (1995), Nature and Composition of the Continental Crust: A Lower Crustal Perspective, Rev. Geophys., 33, 267-309.

Schlüter, T. (2006), Geological Atlas of Africa, Springer, Berlin, 272 pp.

van der Hilst, R., S. Widayantoro, and R. Engdahl (1997), Evidence for deep mantle circulation from global tomography, Nature, 386, 578-584.

van der Lee, S., F. Marone, M. van der Meijde, D. Giardini, A. Deschamps, L. Margheriti, P. Burkett, S.C. Solomon, P.M. Alves, M. Chouliaras, A. Eshwedi, A.S. Suleiman, H. Gashut, M. Herak, R. Ortiz, J.M. Davila, A. Aguirre, J. Vila, and K. Yelles (2001), Eurasia-Africa Plate Boundary Region Yields New Seismographic Data, EOS Trans. AGU, 82(51). 
Vernon, F., R. Mellors, J. Berger, A. Edelman, A. Al-Amri, J. Zollweg, and C. Wolfe (1996), Observations from regional and teleseismic earthquakes recorded by a deployment of broadband seismometers in the Saudi Arabian Shield, EOS Trans. AGU, 77, 478.

Wessel, P., and W.H.F. Smith (1998), New, improved version of Generic Mapping Tools released, EOS Trans. Amer. Geophys. U., 79, 579.

Zhao, M., C.A. Langston, A.A. Nyblade, and T.J. Owens (1999), Upper mantle velocity structure beneath southern Africa from modeling regional seismic data, J. Geophys. Res., 104, 4783-4794. 


\section{Figure captions}

Figure 1. Tectonic map of Africa. Platform and shield areas are indicated by the single and double hatched lines. Deep basins are noted by the $2.5 \mathrm{~km}$ sediment thickness contours (gray lines). Plate boundaries are indicated by the thick black lines. The African Superswell is outlined by the dashed lines.

Figure 2. Path map of surface wave dispersion measurements for Africa and Arabia, shown for $50 \mathrm{sec}$ Rayleigh waves. Yellow circles indicate events, red triangles indicate stations, and blue lines indicate paths.

Figure 3. Group velocities (in $\mathrm{km} / \mathrm{s}$ ) for $20 \mathrm{sec}$ and $60 \mathrm{sec}$ Rayleigh waves. Slow velocities are indicated in red and fast velocities in blue.

Figure 4. Uncertainties (in $\mathrm{km} / \mathrm{s}$ ) of group velocities for $20 \mathrm{sec}$ Rayleigh waves. Low uncertainties are indicated in red and high uncertainties in blue. Uncertainties are generally low in southern Europe, the Middle East, and East Africa, and higher in oceanic regions.

Figure 5. Examples of grid search for crustal structure from a) West Africa and b) East Africa. In each figure, the panels to the left show the fit of the model (solid and dashed lines) to the tomographic models (symbols), while the panels to the right indicate the resulting 1-D model.

Figure 6. Crustal and upper mantle structure of Africa. a) Crustal thickness map (in km), b) Average crustal shear velocity map (in km/s), c) Upper mantle shear velocity (Sn) map (in km/s), and d) Input sedimentary thickness map (in $\mathrm{km}$ ).

Figure 7. Horizontal cross sections showing the shear-wave velocity (in km/s) at a) 100, b) 150, c) 200 , and d) $250 \mathrm{~km}$ depth. The figures correspond well to the upper mantle values from Ritsema and van Heijst (2000). 
Figure 8. Cross-sections traversing the model. a) Map showing the location of cross-sections shown below, along with a simplified crustal thickness map. Dashed lines outline the African Superswell. b) Cross-section A-A' extending from the north Atlantic Ocean to the Indian Ocean. Values along the profile indicate the S-wave velocities in the lid. c) Cross-section B-B' extending from the south Atlantic Ocean to the Iranian Plateau. In both $\mathrm{b}$ and $\mathrm{c}$, the numbers indicate the shear wave velocities at the top of the mantle. Abbreviations the same as in Figure 1. 
Tectonic Map of Africa

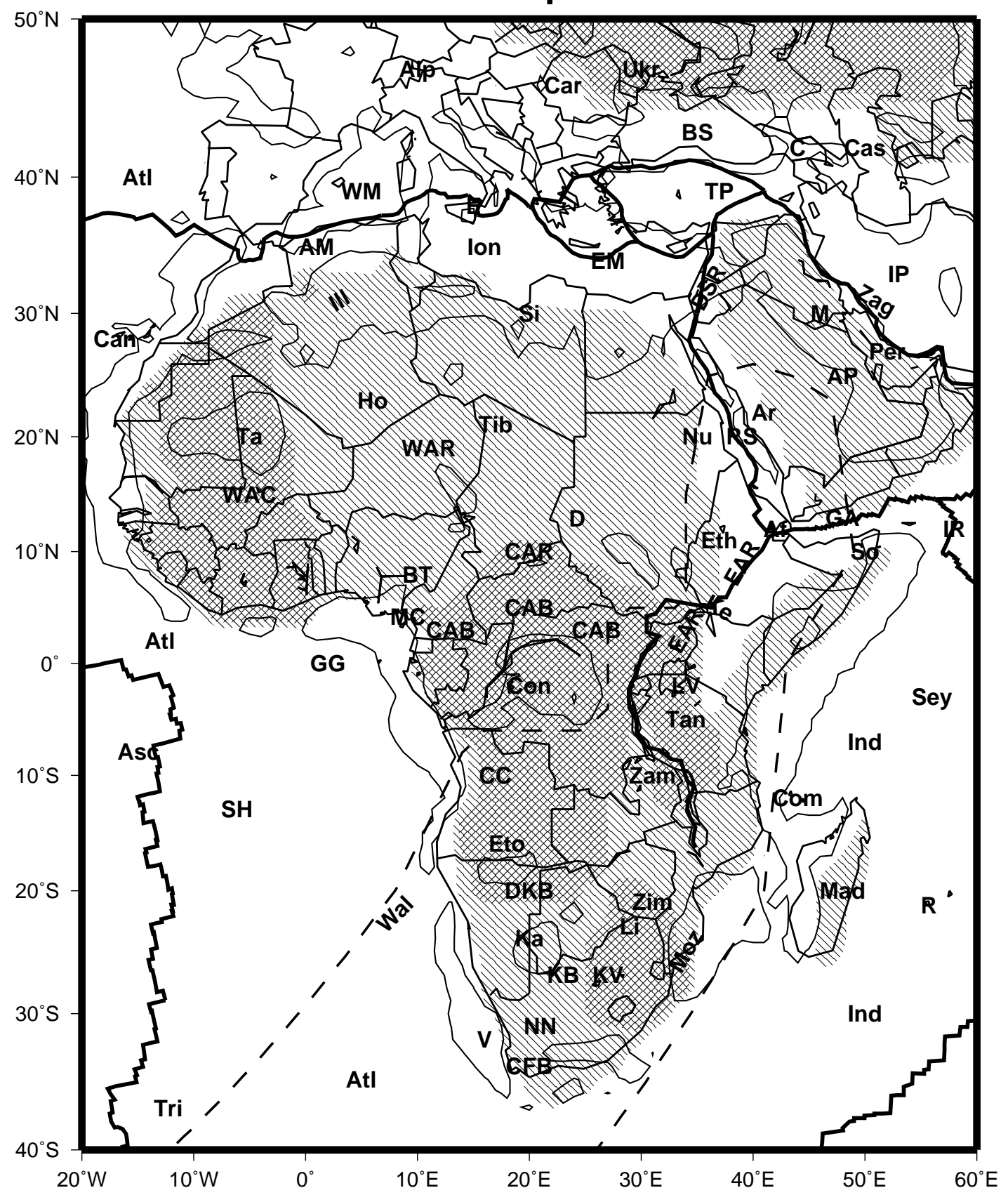

Af=Afar Triple Junction, Alp=Alps, AP=Arabian Platform, Ar=Arabian Shield, AM=Atlas Mts, Asc=Ascension I., Atl=Atlantic Ocean, BT=Benue Trough, BS=Black Sea, Can=Canary Is., Car=Carpathians, Cas=Caspian Sea, $\mathrm{C}=$ Caucasus, $\mathrm{CAB}=\mathrm{C}$.African belt, $\mathrm{CAR}=\mathrm{C}$.African Rift, $\mathrm{CFB}=\mathrm{Cape}$ Fold Belt, $\mathrm{Com}=$ Comores $\mathrm{I}$., Con=Congo Basin, $\mathrm{CC}=$ Congo Craton, $\mathrm{D}=$ Darfour, DKB=Damar-Katanga Belt, DSR=Dead Sea Rift, E=Etna, EAR=E.African rift, EM=E.Mediterranean, Eth=Ethiopian Plateau, Eto=Etosha Basin, GA=Gulf of Aden, GG=Gulf of Guinea, Ho=Hoggar, Ill=Illizi Basin, Ion=Ionian Basin Ind=Indian Ocean, IP=Iranian Plateau, IR=Indian Ridge, KB=Kheiss Belt, $\mathrm{KV}=$ Kaapvaal Craton, $\mathrm{Ka}=$ Kalahari Basin, $\mathrm{Ke}=$ Kenya Rift, Li=Limpopo Belt, LV=Lake Victoria, Mad=Madagascar, $\mathrm{MC}=$ Mt.Cameroon, M=Mesopotamian Foredeep, Moz=Mozambique Basin, NN=Namaqua-Natal Belt, Nu=Nubian Shield, Per=Persian Gulf, R=Reunion, RS=Red Sea Rift, Sey=Seychelles, Si=Sirt Basin, SH=St.Helena, So=Somali Basin, Tan=Tanzania Craton, Ta=Taoudenni Basin, Tib=Tibesti, Tri=Tristan da Cunha, TP=Turkish Plateau, Ukr=Ukranian Shield, V=Vema Seamount, Wal=Walvis Ridge, WAC =W.African craton, WAR=W.African Rift, $\mathrm{WM}=$ W.Mediterranean, Zag=Zagros Mts., Zam=Zambia Craton, Zim=Zimbabwe Craton. 


\section{0 second Rayleigh}

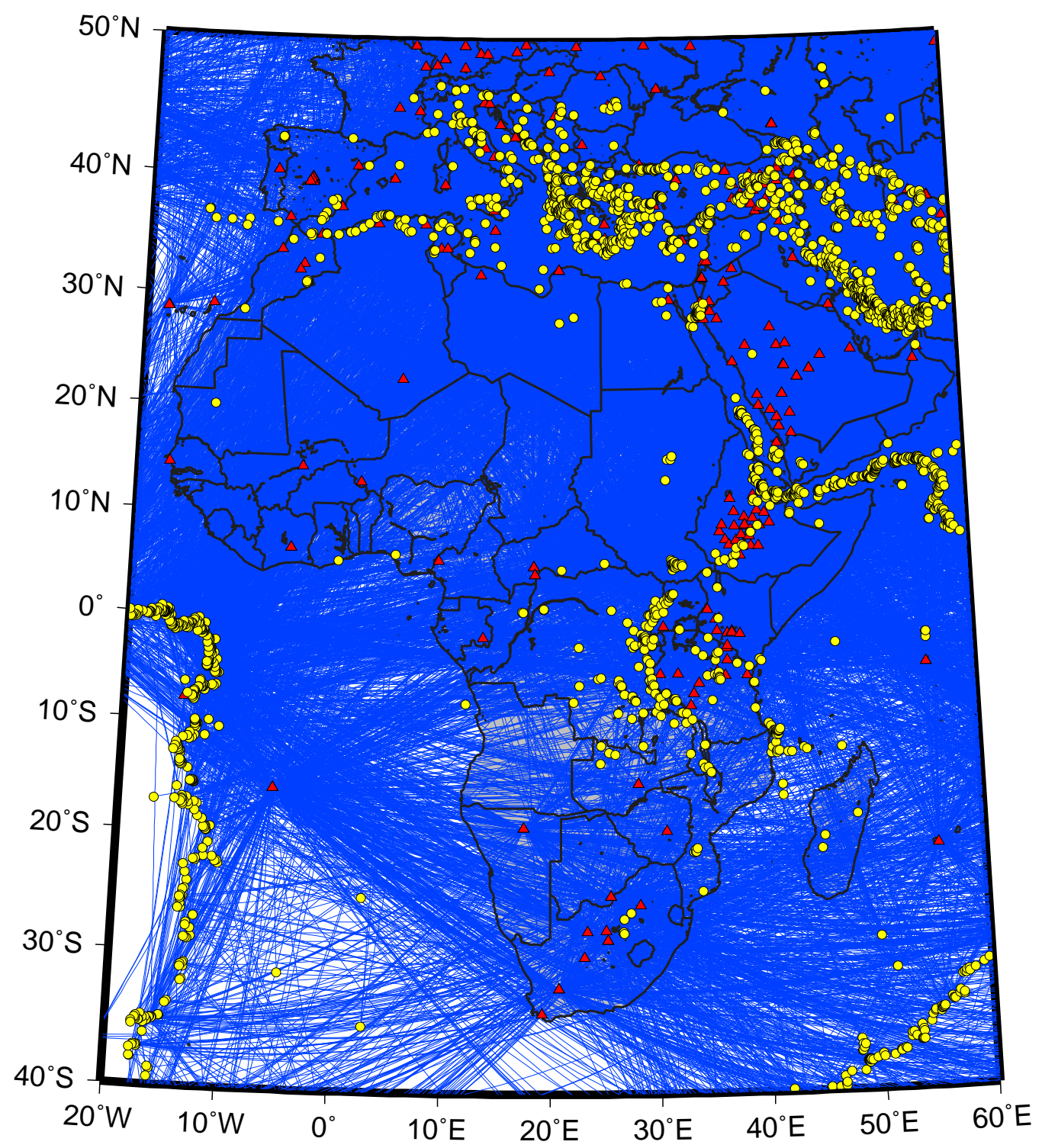

Figure 2 

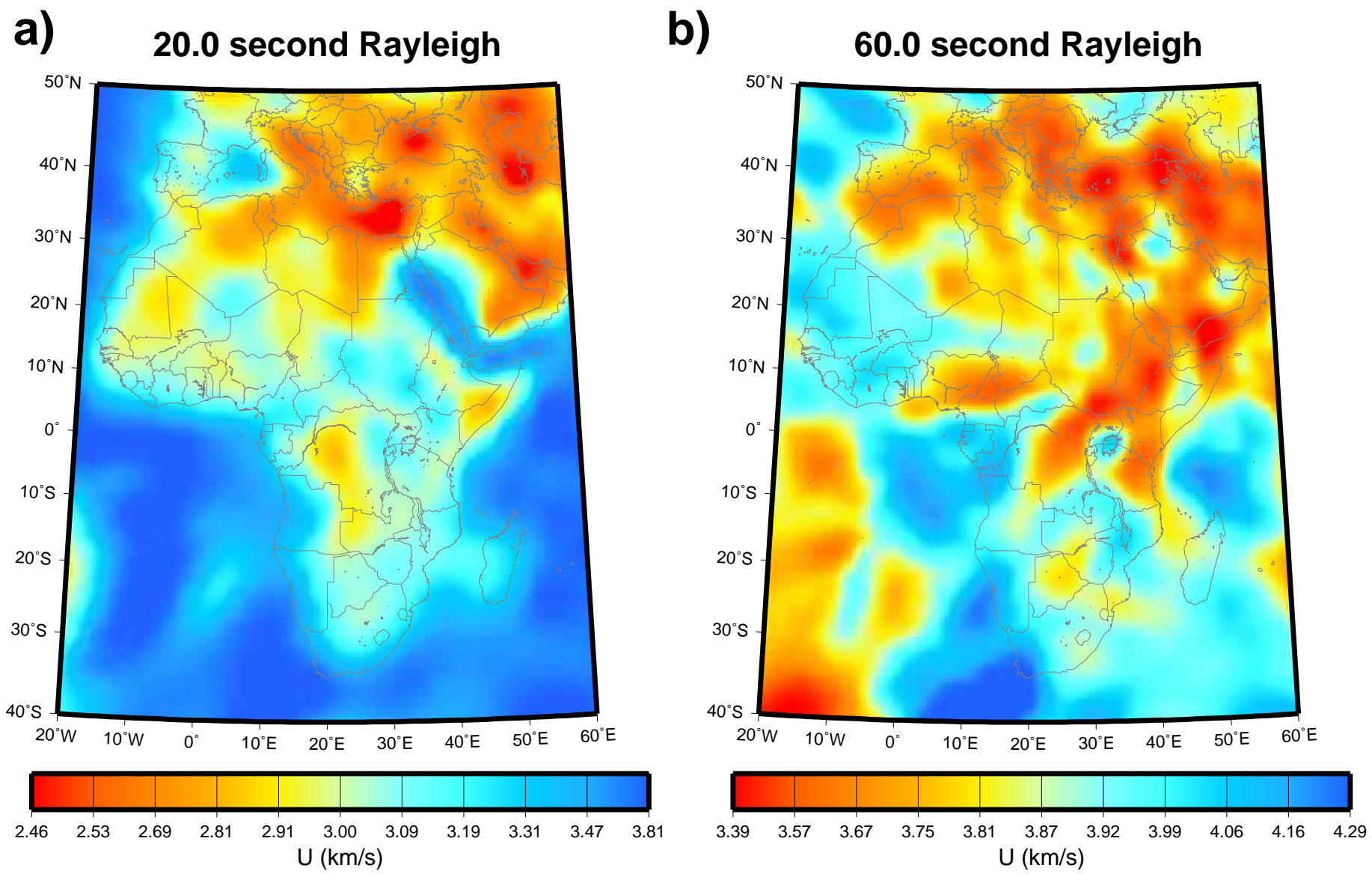


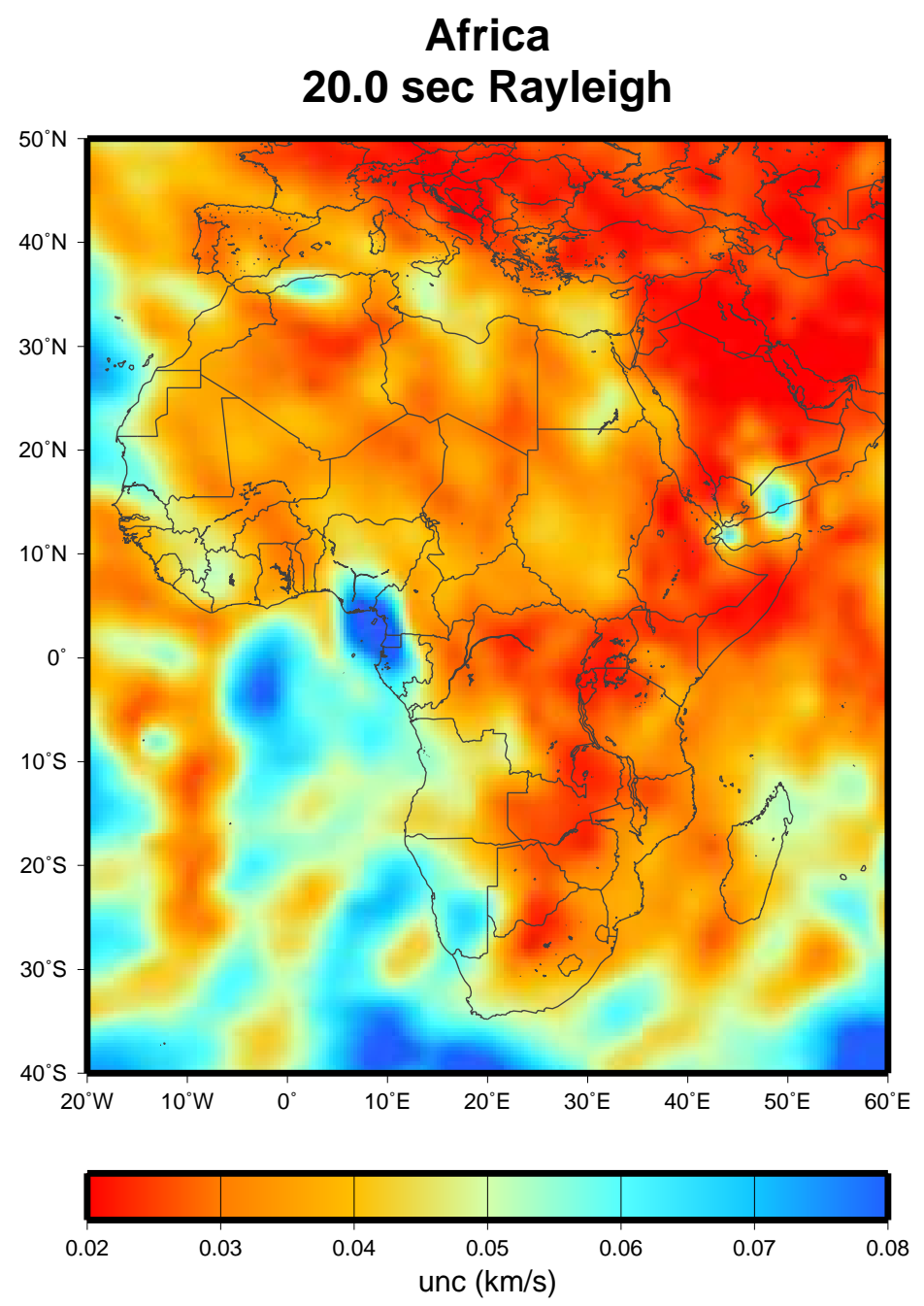

Figure 4 
a)

West Africa
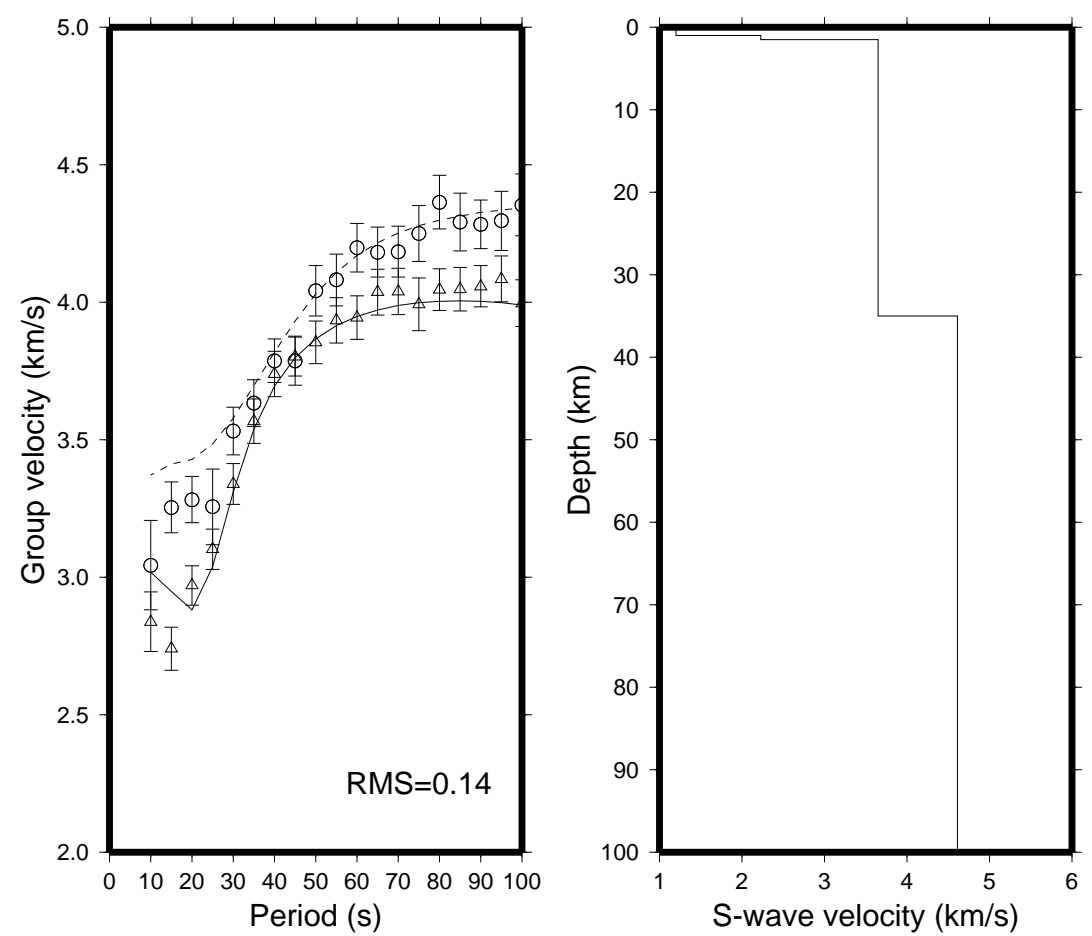

b)

East Africa
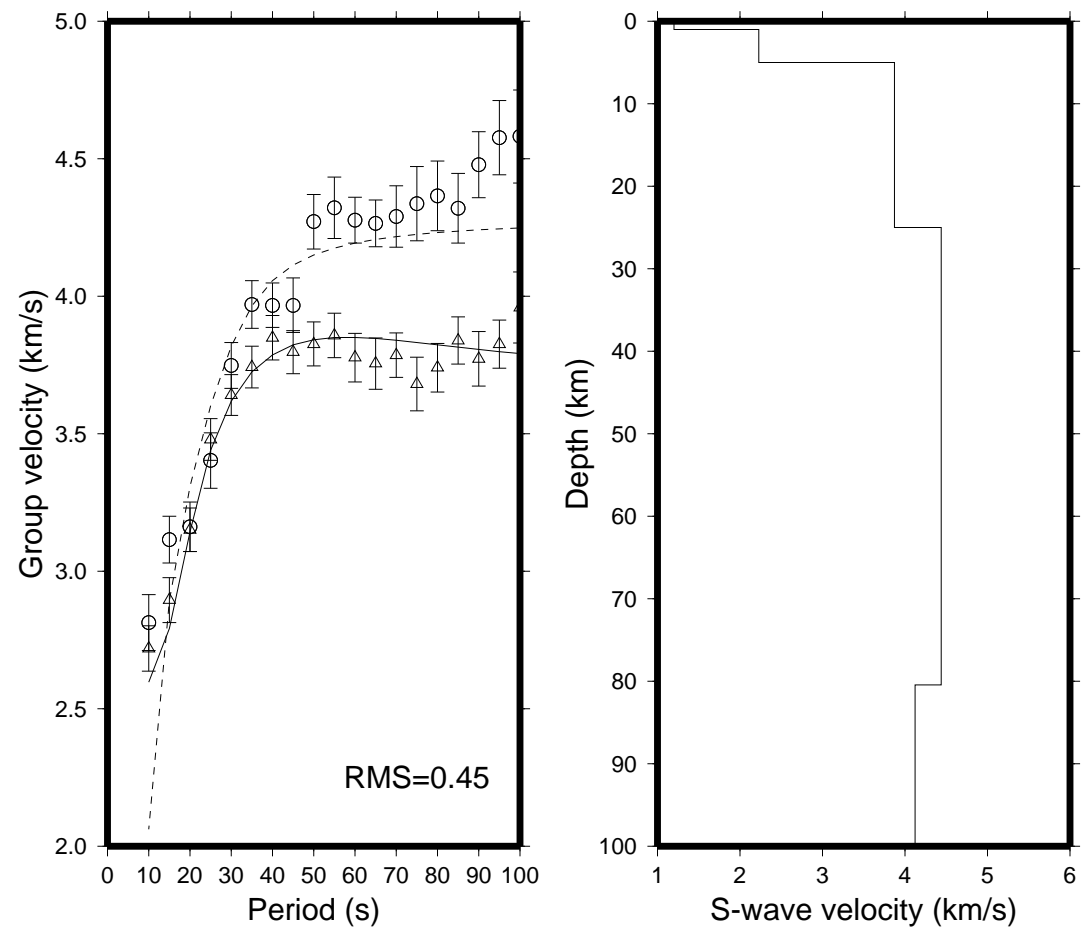

Figure 5 
a)

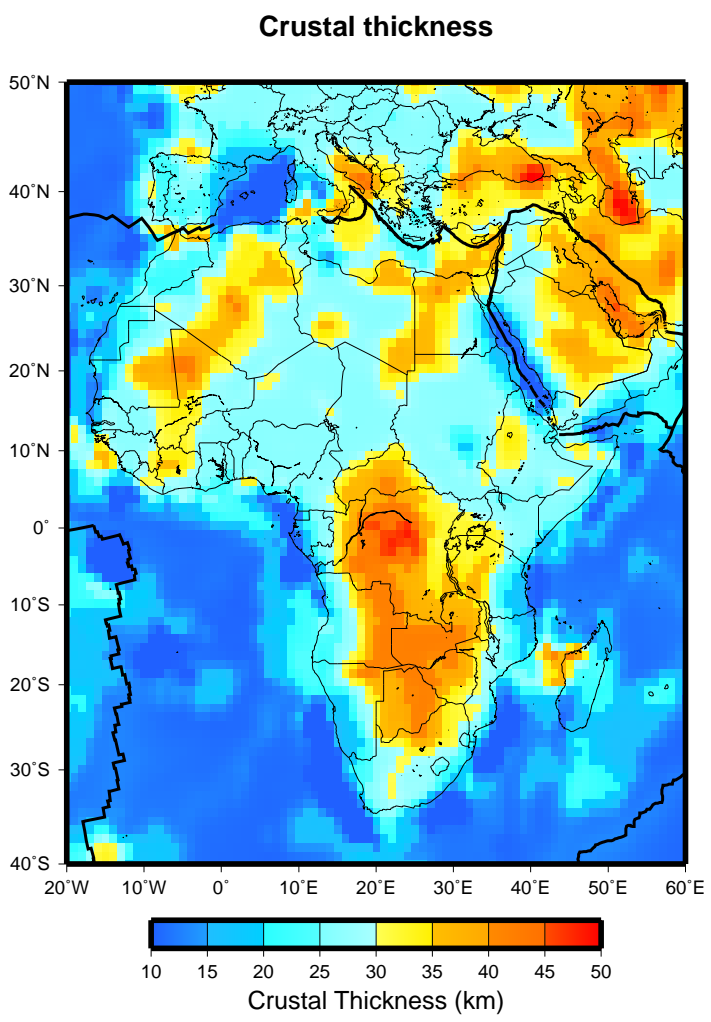

c)

pper Mantle Shear Velocity

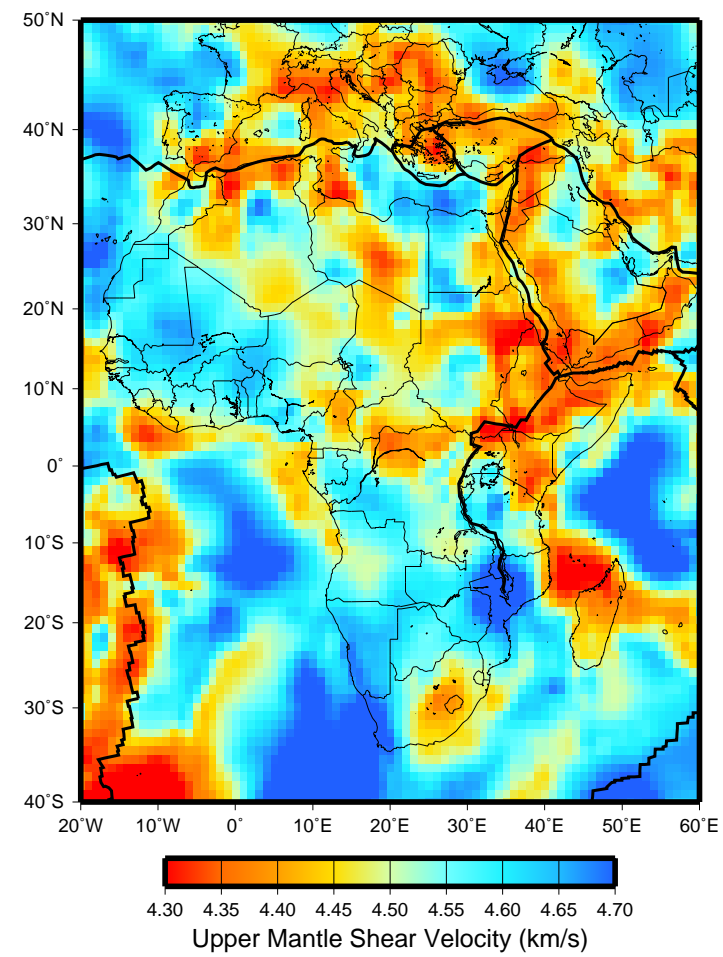

b)

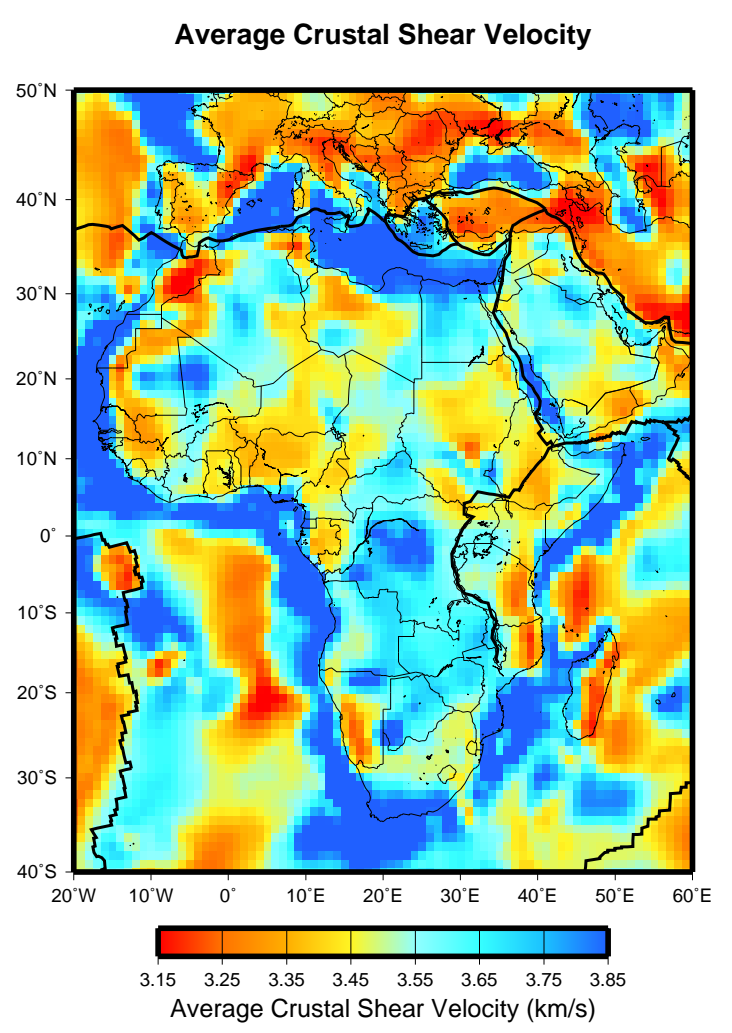

d)

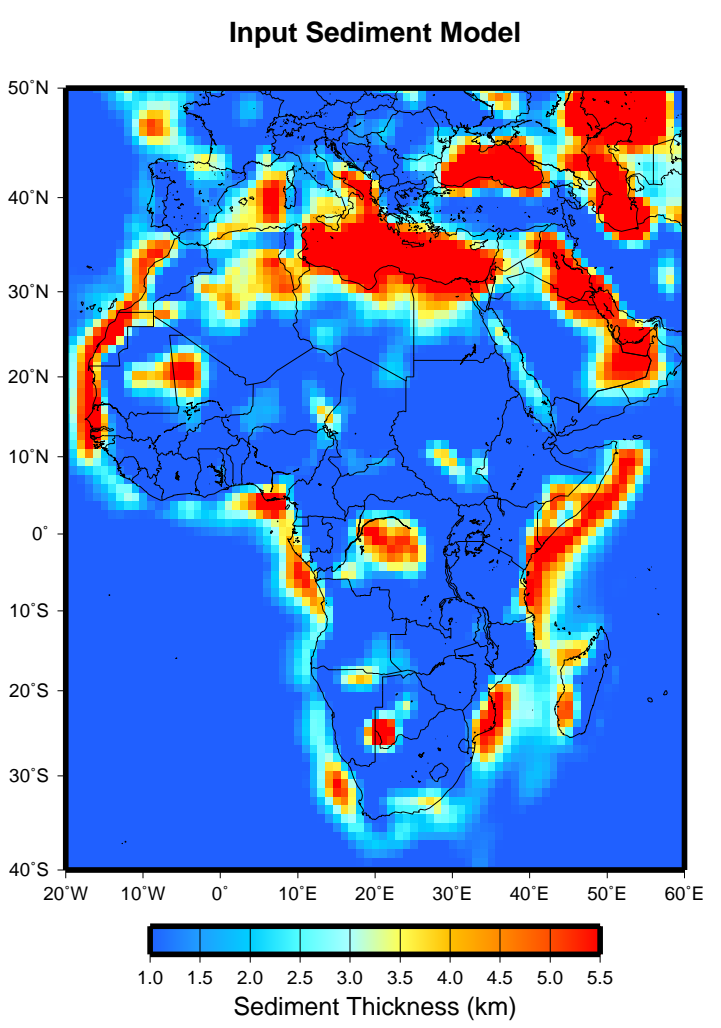


a)

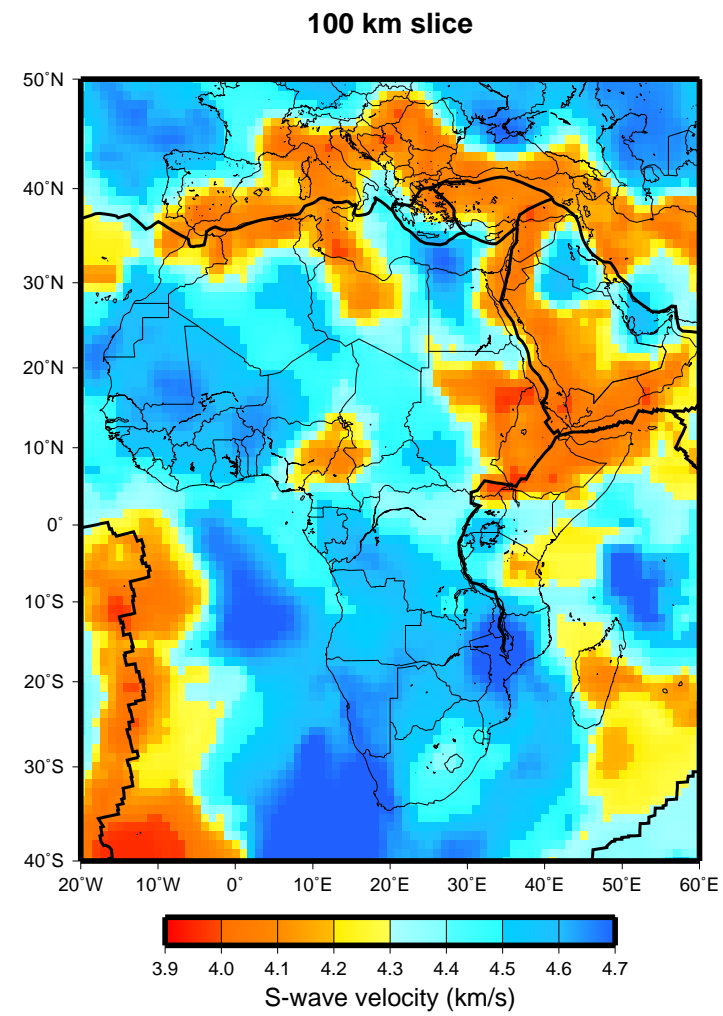

c)

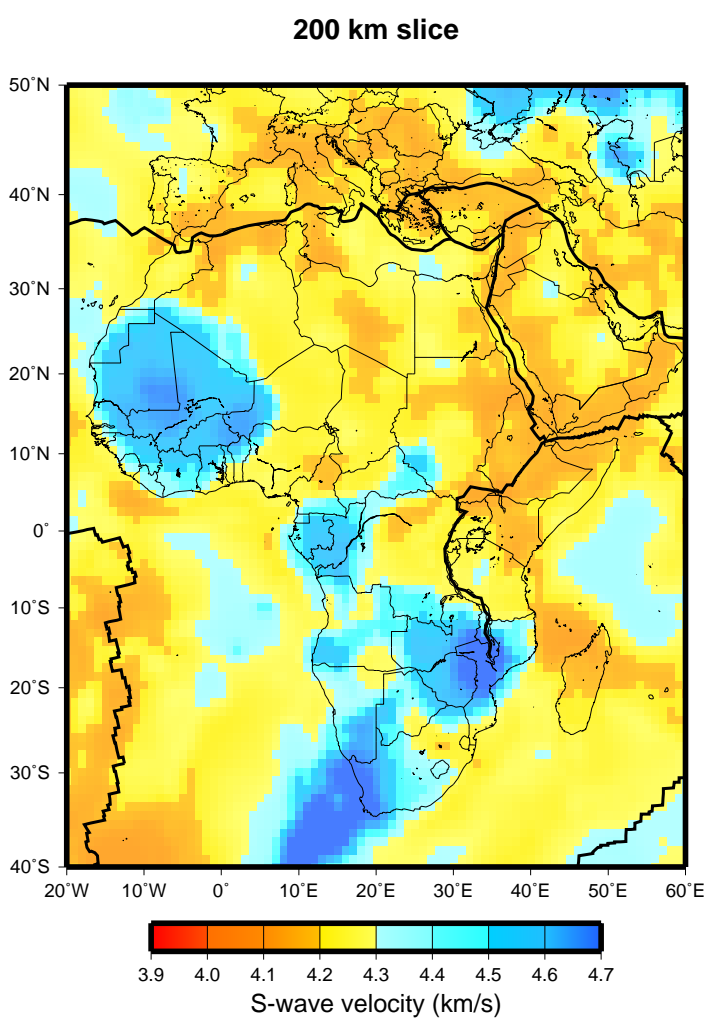

b)

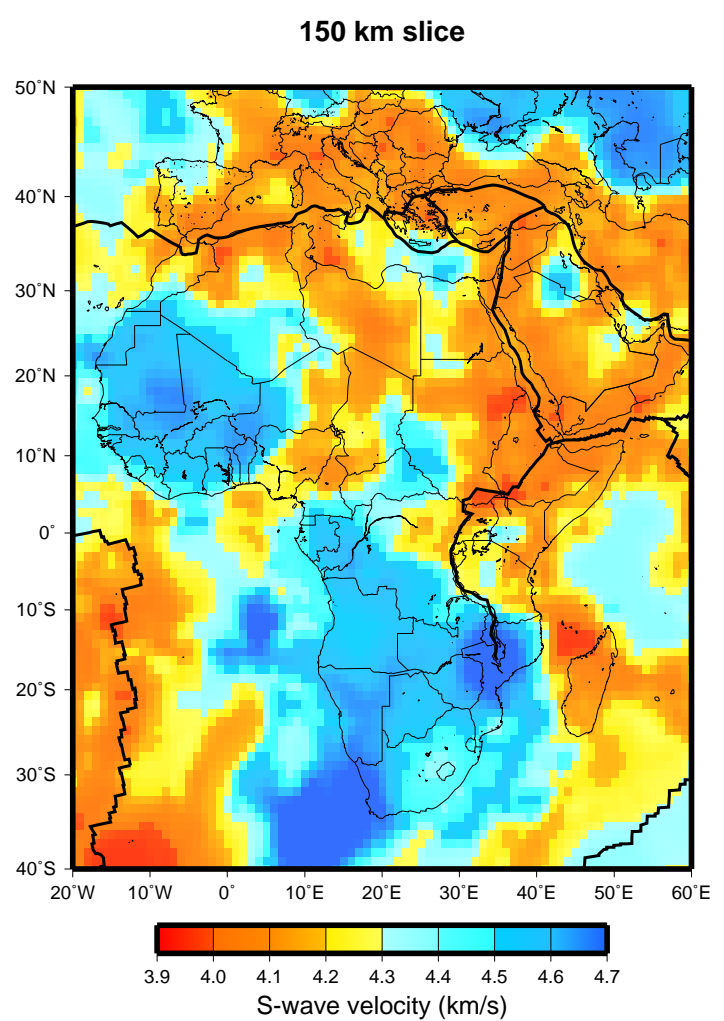

d)

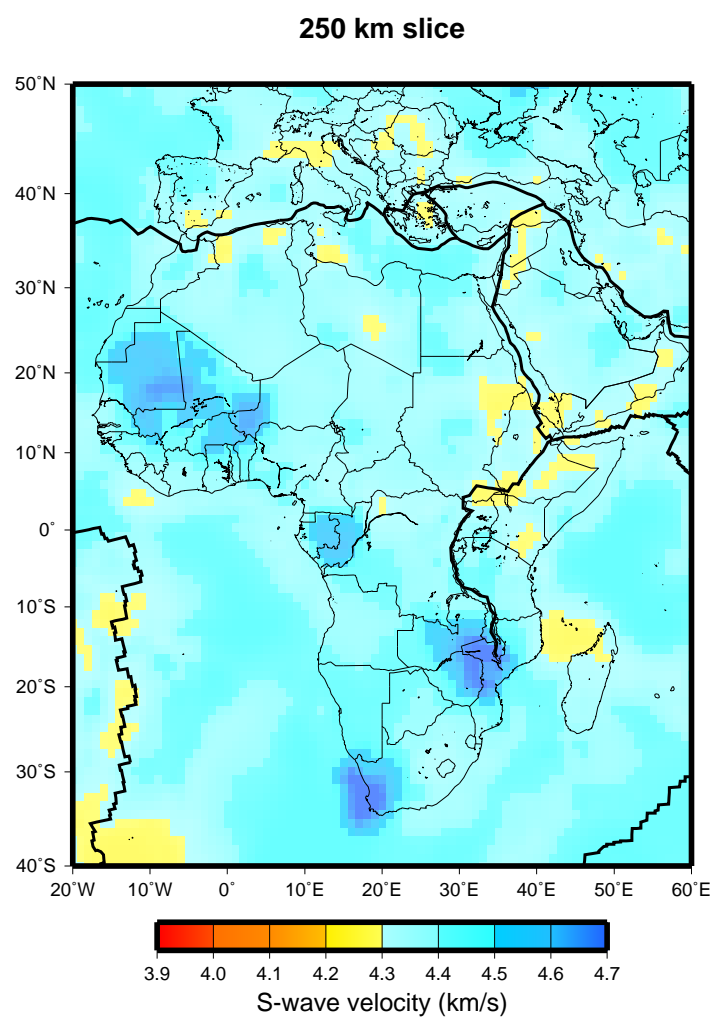




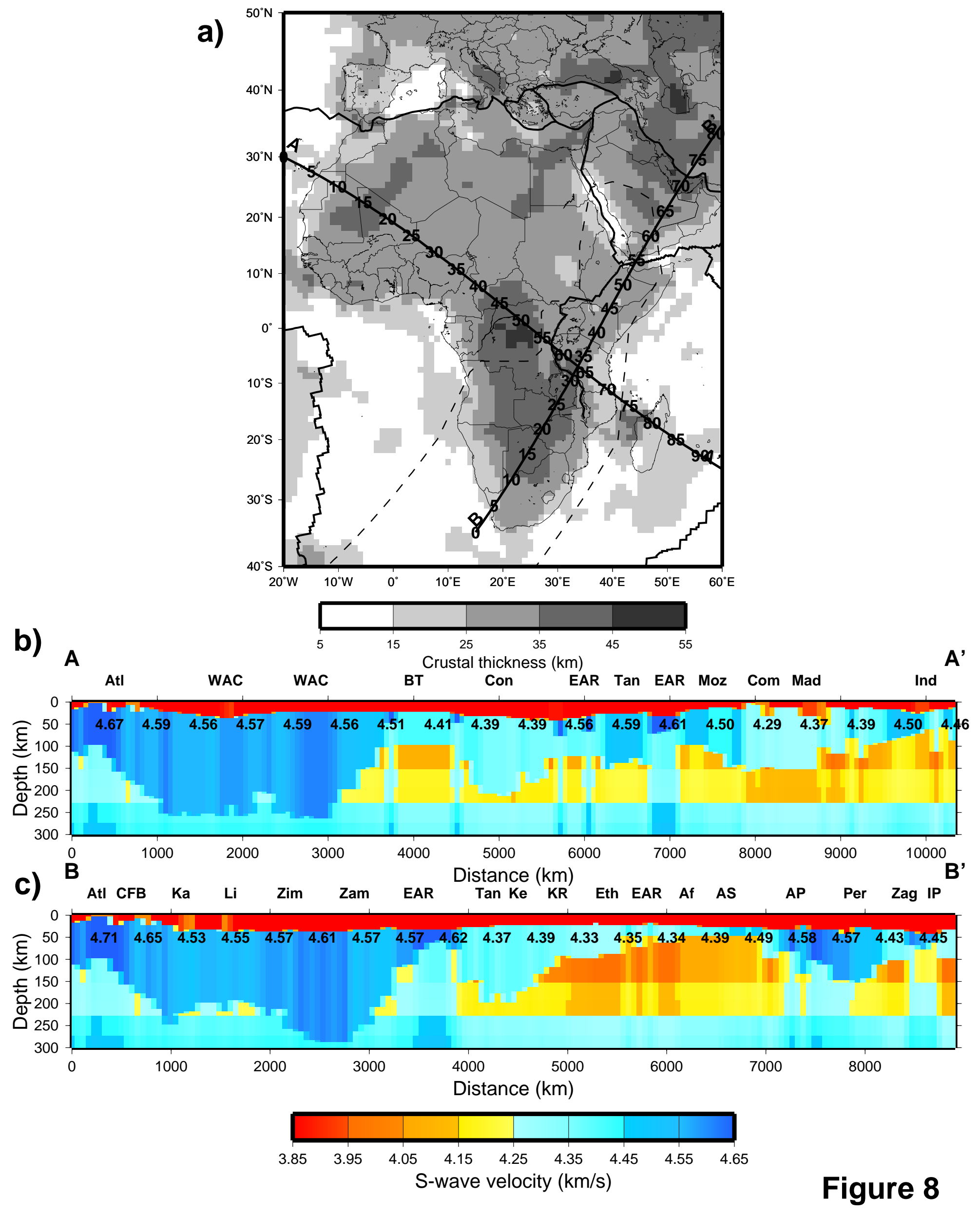

